\title{
Conceptions of 'the international' beyond the core: Turkey in the post-Cold War era
}

\section{Mine Nur Küçük}

To cite this article: Mine Nur Küçük (2018) Conceptions of 'the international' beyond the core: Turkey in the post-Cold War era, Turkish Studies, 19:4, 571-592, DOI: 10.1080/14683849.2018.1468757

To link to this article: https://doi.org/10.1080/14683849.2018.1468757

册 Published online: 27 Apr 2018.

Submit your article to this journal

Џll Article views: 248

View Crossmark data ¿ 


\title{
Conceptions of 'the international' beyond the core: Turkey in the post-Cold War era
}

\author{
Mine Nur Küçük \\ Department of International Relations, Bilkent University, Ankara, Turkey
}

\begin{abstract}
International relations (IR) scholarship rests on a conception of 'the international' based on the experiences of core actors. A burgeoning literature has asked what IR would look like if non-core actors' conceptions of 'the international' were also considered. This article analyzes conceptions of 'the international' in Turkey as an example of a non-core context. In doing this, the article develops and offers a new analytical framework which breaks down the components of conceptions of 'the international' into three questions: 'what', 'who', and 'where' of world politics - namely, the main dynamics of world politics, the main actors of world politics, and the location where world politics takes place. I utilize this framework to empirically analyze the election manifestos and party programs of the political parties in Turkey, and tease out their conceptions of 'the international.' The article concludes by considering the implications of these findings for IR scholarship in general.
\end{abstract}

ARTICLE HISTORY Received 7 May 2017; Accepted 16 January 2018

KEYWORDS Turkey; political parties; Turkish politics; international relations; international relations theory

\section{Introduction}

The discipline of International Relations (IR) is about relations among different and diverse actors which together constitute world politics. Yet the main concepts, categories, and prevalent understandings in IR do not always reflect this diversity. ${ }^{1}$ This is because these are drawn mainly from the particular experiences of core actors, whereas ideas and experiences of non-core actors do not always make it into IR scholarship. ${ }^{2}$ A growing body of IR literature problematizes the issue of overlooking non-core actors' ideas and experiences, and asks what IR would look like if views of non-core actors were considered. ${ }^{3}$ This article aims to contribute to this literature by examining the conceptions of 'the international' in a non-core context, namely 
Turkey, so as to offer one way of moving beyond this current state of affairs in the discipline. ${ }^{4}$

The ideas of Turkey's leaders and policy makers in analyzing the country's foreign policy has been on the Foreign Policy Analysis (FPA) literature's research agenda for a number of years. FPA studies highlight the ways in which ideational factors such as worldviews, role conceptions, visions, and perceptions shape different aspects of Turkish foreign policy. ${ }^{5}$ Otherwise informed by different theoretical and methodological approaches, what these studies commonly argue is the necessity to inquire into the views of decision makers to analyze Turkish foreign policy making. That said, this article differs from FPA studies on Turkey in two ways. First, it takes 'the international' as its core concept as opposed to other terms as noted above. I derive this concept from a specific discussion in IR theory literature. In this literature, 'the international' is defined as a 'distinct space of social interaction' $^{\text {'6 }}$ and a 'distinct location of politics." As will be elaborated below, studying non-core actors' understandings of 'the international' constitutes one of the central topics in this discussion. Second, and relatedly, this article is interested in the conceptions of 'the international' in Turkey for their implications for IR theorizing in general. In this sense, it differs from the FPA literature on Turkey, which is concerned with the impact of ideational factors on policy practices of Turkey.

In IR, the importance of and the necessity for studying the ideas and experiences of non-core actors with regards to theorizing world politics have been discussed by a wide group of scholars. ${ }^{8}$ Accordingly, they define IR as a discipline which should be 'devoted to relationship, interconnection, diversity and discontinuity. ${ }^{9}$ However, they underscore that IR's exclusive focus on the roles, ideas and experiences of core actors, and its relative disinterest on non-core actors render the discipline inadequate to the task of understanding the international. ${ }^{10}$ That is because, although they seldom get recognition for their significant roles, ${ }^{11}$ non-core actors are, in fact, shaping different aspects of world politics including, but not limited to, the modern state system, capitalism, and ideas. ${ }^{12}$ This article is particularly interested in the ideational dimension, i.e. non-core actors' perspectives on world politics. These perspectives are important, suggests Seth, since the 'contestations over meanings' are as significant as the struggles over resources and power in world politics. ${ }^{13}$ However, in IR divergent meanings and historical experiences ${ }^{14}$ have rarely been discussed due to the assumption that the main concepts, categories, and understandings of the discipline are valid across time and space. ${ }^{15}$ Accordingly, although IR is based on the 'peculiar histories, memories, rationales, values, and interests, all bound by time, space, and specific political languages and values,' it does not always reflect on this particularity. ${ }^{16}$ Put differently, there is a 'discrepancy between what IR promises (an explanation or understanding of the international)' on the 
one hand, and 'what mainstream perspectives deliver (a "particular" perspective on the international that is offered as the "universal" story)" on the other. ${ }^{17}$

The limited attention paid to non-core actors' understandings of 'the international' is one case in point. In fact, in IR theoretical examinations on the very concept of 'the international' are rather inadequate, ${ }^{18}$ let alone the conceptions of 'the international' as found in non-core contexts. ${ }^{19}$ To address this gap, I seek to examine the conceptions of 'the international' in Turkey so as to demonstrate how 'the international' is understood in one such non-core context. To achieve this, I follow those studies which suggest that there is 'no essential, historically transcendent meaning we can confer upon the space of the international. ${ }^{20}$

Yet, in the literature no framework has hitherto been developed for studying the conceptions of 'the international' in different contexts. This article aims to contribute by developing and offering one such framework. The proposed framework attempts to extract actors' understandings of 'the international' by focusing on their views regarding 'what', 'who' and 'where' of world politics - namely, main dynamics of world politics, main actors of world politics, and location of world politics. Put differently, while I analyze the case of Turkey, I also offer an analytical framework for teasing out the conceptions of 'the international' in any given context. I do this by breaking down the components of conceptions of 'the international' into three questions: the 'what', 'who' and 'where' of world politics. These three questions, taken together, point to their conceptions of 'the international.' By the 'main dynamic of world politics' I mean the 'basic ideas' of the actors as to 'what makes the world go around,' i.e. the mechanisms through which world politics unfolds. ${ }^{21}$ By 'main actors of world politics' I mean those entities that are viewed by actors as shaping world politics. 'The location of world politics' refers to the question of 'where does world politics take place?' and it aims to understand actors' views regarding 'whether domestic and foreign affairs are separate or convergent' or 'whether any boundaries that differentiate them are firm or porous. ${ }^{, 22}$

The article applies this framework to the case of Turkey by analyzing the election manifestos and party programs of the political parties of the country. The selection of political parties stems from the fact that they have been one of the most influential actors in understanding Turkey's political life. ${ }^{23}$ For studying political parties' views, I employ discourse analysis as my method. Following Ó Tuathail and Agnew, discourse is understood here 'as sets of socio-cultural resources used by people in the construction of meaning about their world and their activities'. ${ }^{24}$ The article will analyze the meanings political parties attribute to the realm of 'the international' through engaging with their discourses as found in their election manifestos and party programs. In what follows, after briefly introducing the party 
system in Turkey, I look at 'nationalist-right', 'center-right', 'Islamist-right', 'center-left' and 'pro-Kurdish' parties respectively. ${ }^{25} \mathrm{I}$ conclude by pointing out to the political parties' shared characteristics so as to identify the contours of the conceptions of 'the international' in Turkey. I will suggest that these characteristics indicate crucial differences when the prevalent conceptions of 'the international' in IR scholarship is considered. This finding, in turn, reveals how IR scholarship would look like if ideas and experiences of noncore actors were considered.

\section{The conceptions of 'the international' among Turkish political parties}

In Turkey, political parties emerged in the late nineteenth and early twentieth centuries. ${ }^{26}$ From the foundation of the Republic in 1923 until 1946, Turkey experienced a one-party system under the Republican People's Party (Cumhuriyet Halk Partisi, CHP). With the transition to democracy thereafter, political parties' significance and impact increased in Turkish politics. During the 1950s, there was a two-party system in which the CHP and Democratic Party (Demokrat Parti, DP) (1946-60) were the two major parties in the country. From 1960 to 1980, the number of political parties increased and a 'fragmented' multi-party system emerged as a result. ${ }^{27}$ This period ended with the 1980 coup which banned all political parties and established a military rule that lasted until 1983. Following the end of the military rule, a multi-party system was restored with the Motherland Party (Anavatan Partisi, ANAP) forming the governments until 1991. During the 1990s, Turkey experienced 'extreme fragmentation' and coalition governments. ${ }^{28}$ Since 2002, Turkey has been experiencing one-party majority governments under the Justice and Development Party (Adalet ve Kalkınma Partisi, AKP).

The following sections examine the political parties' election manifestos and party programs published in the time period spanning from 1990 to $2015{ }^{29}$ The reasons for limiting the analysis to this period is related, firstly, to make the scope of the analysis more manageable. Secondly, the postCold War is an interesting period as the core parameters in world politics witnessed significant transformations. For Turkey, it was a period where the country's location, role and identity were subject to intense debate. ${ }^{30}$

Instead of focusing only on the political parties represented in the parliament, I choose to analyze those parties which gained at least one-million votes in the general elections. This decision is related with the ten percent election threshold in Turkey which undermines 'the fairness of political representation' regardless of the importance of political parties for understanding Turkish politics. ${ }^{31}$ Focusing on those parties that received at least one-million votes is one way to transcend this problem. ${ }^{32}$ The thirteen parties which qualified this criterion and are covered in the analysis include Democratic Left 
Party (DSP), Democratic People's Party (DEHAP), AKP, ANAP, Nationalist Action Party $(M H P)$, People's Democracy Party (HADEP), Peoples' Democratic Party $(H D P)$, CHP, Social Democratic Populist Party (SHP), True Path Party/Democrat Party $(D Y P / D P)$, Virtue Party $(F P)$, Welfare Party $(R P)$, and the Young Party $(G P) .^{33}$

Before I proceed, two caveats are in order. First, the conclusions of this article are limited to the examination of documents produced in the postCold War era. The language and particular references used in these documents can be traced back to discourses formed in earlier periods that precede the period under investigation. However, I have not attempted to trace such historical and linguistic linkages, continuities or changes. Rather, I am interested in examining how 'the international' is made sense of in Turkey in this particular era as an illustration for discussing IR's assumption that its conception is universally valid. Second, although there are multiple contextual factors that lead to the emergence of particular understandings about world politics in Turkey, what this article aims to accomplish is limited to highlighting conceptions of 'the international' in discourses of the political parties. By doing this, I attempt to discuss what IR would look like if the conceptions of 'the international' as found in Turkey were also considered.

\section{Nationalist-right (MHP)}

The MHP is the successor of the Republican Peasant Farmer's Nation Party (CKMP) (1948-69) which was the first nationalist-right party in Turkey. The party was named the MHP in 1969 and from then on it is known to be one of the largest and most significant representative of the nationalistright in Turkey.

For the MHP, there are two main dynamics of world politics. First, the MHP views world politics as shaped by the 'double standards and hypocrisy' of powerful actors. These actors, who remain unspecified, seek to maintain the status quo which serves their interests, and they apply different standards toward less powerful actors. What emerges from such behaviors of powerful actors is, in their words, the 'bandit law' in world politics. ${ }^{34}$ For the MHP, the 'bandit law' refers to the powerful actors' hypocritical ways of acting in world politics at the expense of some other actors, which creates a distrustful and hostile world for the latter. Accordingly, while powerful actors draw advantages from the current features of world politics, it is the 'oppressed nations' (mazlum milletler) that are most negatively affected by it. ${ }^{35}$ For the party, the 'oppressed nations' refers to Turkic and Muslim nations, which brings us to the second dynamic of world politics, according to the MHP. ${ }^{36}$

The second dynamic is Turkey's centrality to world politics. For the MHP, Turkey is a 'central country' when the Turkic and Islamic worlds are 
considered. The centrality of Turkey is explained with reference to its 'pioneering' role in preventing 'blood and tears' of Turkic and Islamic communities and helping them to recover their 'dignity. ${ }^{37}$ This role, so the argument goes, is related with historical and cultural 'realities' of Turkey. ${ }^{38}$ Even though the MHP does not specify what these 'realities' refer to, the party documents exclusively imply the existence of earlier polities, such as the Ottoman Empire, in these parts of the world. It is this attribution of centrality to Turkey that leads the party to consider it to be 'the main target' of aforementioned powerful actors of world politics. ${ }^{39}$ Indeed, in the party documents arguments such as Turkey being surrounded by a 'circle of fire' and a 'belt of political plots' and facing 'exploitation and derogation in the hands of global powers' are observed extensively. ${ }^{40}$

As for the actors of world politics, the MHP considers states as the main actors of world politics. The importance of states does not only stem from the fact that it is their behaviors that shape world politics, but also from the belief that their existence and strength make the world more 'peaceful.' What this means is that states, as the most important human group, ensures the 'survival' of people in a 'dangerous' world. However, for the MHP there are certain actors who are more influential in shaping world politics than others. What renders these actors more influential is their ownership of certain material and non-material resources. Material elements include economic, military, technological, and demographic resources, ${ }^{41}$ whereas non-material resources are understood as the ability to shape dominant ideas in world politics. ${ }^{42}$ For the party, 'human rights' is one such idea which is a 'tool' in the hands of the powerful actors to 'ignore or annihilate the national and humane rules' and to 'enlarge their networks of privilege. ${ }^{43}$ The party utilizes terms such as 'external powers' ( $d \imath$ ı̧ güçler) to describe the actors who possess these resources. ${ }^{44}$ That said, these terms remain ambiguous in the party documents. For instance, while at one point it is 'Western countries controlling the Security Council of the United Nations, ${ }^{, 45}$ at other times it is 'global economic empires' or 'international civil society organizations $^{46}$ that the party labels as 'external powers.'

Regarding the location of world politics, the MHP focuses on the realm of inter-state relations. That said, the MHP has an inward-oriented view in that it exclusively focuses on how inter-state relations affect domestic politics, and not vice versa. In other words, for the MHP, the so-called powerful actors' presumed 'hostility' to Turkey mostly manifests itself in Turkey's internal affairs. This view can be extracted particularly from the party's approach to the Kurdish problem and Turkey's European Union (EU) membership process. Regarding the former, the MHP frequently underlines 'the external dimension of terrorism' which triggers terrorist activities through the help of 'collaborators' inside the country. ${ }^{47}$ As for the latter, the party argues 
that the EU criteria 'correspond with the expectations of the divisive elements' within the country which target 'our national unity and integrity. ${ }^{38}$

To summarize, the MHP views 'the international' as a 'hierarchical' realm in which Turkic and Islamic communities face various inequalities. This hierarchy, the MHP considers, is generated by some (unnamed) 'powerful actors' with the aim to serve their own interests. As for the location of world politics, the MHP puts emphasis on the effects of inter-state relations on domestic politics. These effects are mostly understood in negative terms, i.e. how the activities of other states trigger and intensify problems in domestic politics.

\section{Center-right (ANAP, DYP-DP, GP)}

Founded in 1983, the ANAP is a center-right political party which controlled the government single-handedly until 1991. The DYP is a successor of the DP (1946-60) and the Justice Party (AP) (1961-80), the former significant representatives of the center-right in Turkey. Following the closure of the AP, the DYP was established in 1983. Failure to pass the election threshold in the 2002 elections resulted in a change of leadership and the name of the party. Accordingly, in 2007 the DYP was renamed as the Democrat Party $(D P)$. The GP is a center-right party which was founded in 2002 by a business tycoon, Cem Uzan. The party participated in the 2002 and 2007 elections.

In the documents of these center-right parties, two main dynamics of world politics, which are somewhat contradictory, are identified. Firstly, especially evident in the ANAP and the DYP, the main dynamic in world politics is understood as the neoliberal economy and the opportunities that it provides. This view is especially evident in parties' take on globalization which is considered as 'liberalization,' i.e. believing that neoliberal policies would bring 'prosperity, freedom, peace, and democracy for all. ${ }^{49}$ While incessantly underscoring the benefits of neoliberalism, the parties explain problems in the world with reference to inabilities of actors to comply with neoliberalism. For instance, while the DYP identifies poverty as one of the most significant problems in the world, it suggests that poverty is caused by rapid population growth which 'stimulates misery and obstructs the prevention of hunger. ${ }^{50}$

The second understanding of the main dynamic of world politics, found especially in the DP and GP, considers the world as a 'hostile' and 'distrustful' place in which 'the struggles over power, interest, and influence occur in merciless way. ${ }^{51}$ This presumed 'hostility' is considered to affect Turkey more than any other country and it is believed that it manifests itself in various different areas from culture to the economy in the country. Consider, for instance, the DP's view on the EU. For the DP, Turkey's EU membership process is 'full of mines' in that the EU's 'enforcements' threaten Turkey's 'independence, national sovereignty, unity and integrity, and border security. ${ }^{52}$ 
As for the actors of world politics states are considered as the most important actors by center-right parties. However, since these parties differentiate states on the basis of their development levels, they view those economically developed, mostly 'advanced Western countries' as the main actors of world politics. ${ }^{53}$ The institutions that are established by these countries, among which European Community/Union and NATO stand out, are also given a considerable space in the documents. ${ }^{54}$

In a rather contradictory manner, the DP and GP hold negative conceptions on these very actors. Accordingly, these parties criticize institutions, such as the World Bank and the International Monetary Fund (IMF), by arguing that they are 'harmful' to Turkey. ${ }^{55}$ These parties also utilize certain unspecified references, such as 'external centers' $\left(d_{\imath}\right.$ ş odaklar $\left.{ }^{56}\right)$ to voice the idea of an existence of actors who shape world politics in accordance with their own interests.

Concerning the location of world politics, the center-right parties focus on the realm of inter-state relations. However, two different understandings are held by different center-right parties in making sense of inter-state relations. The first one holds an inward-oriented understanding. Accordingly, the 'struggles' and 'hostility' in world politics are believed to manifest themselves in Turkey's domestic affairs where actors who have 'bad intensions' against Turkey try to weaken the country. ${ }^{57}$ The second view, on the other hand, is informed by the notion of 'globalization as internationalization. ${ }^{58}$ Having a positive understanding of the increased level of state interactions (particularly regarding volumes of economic exchange) as a result of the process of globalization, this view has a favorable approach towards cooperative relations between countries.

To summarize, the center-right parties hold two different, and somewhat contradictory, conceptions of 'the international'. On one hand this realm is considered as a hostile place where Turkey is targeted by some unspecified actors. On the other hand, neoliberal economy and developed countries dominate the center-right parties' conception of 'the international.' The location of world politics is identified as inter-state relations in both understandings. Where the latter views the intensification of economic interactions between states as a positive phenomenon, the former has a negative and inwardoriented outlook in that the main concern is on how external actors generate various problems within domestic context.

\section{Islamist-right (RP, FP, AKP)}

The RP was a successor of two previously established Islamist-right parties namely the National Order Party (MNP) (1970-71) and the National Salvation Party (MSP) (1972-80). As a result of the closure of the MSP in 1980, the RP was established in 1983. Until its closure on the grounds of violating 
secularism in 1998, the RP remained as the most significant party of the Islamist-right. The FP was established in late 1997 with the cadres of the RP. However, on account of being a focal point of anti-secular activities, the FP was also closed down in 2001. The closure of the FP resulted in the emergence of two Islamist-right parties, one of which is the AKP.

The main dynamics of world politics are identified differently by different Islamist-right parties. Accordingly, for the RP, 'Zionist conspiracies' are the main dynamics in world politics. ${ }^{59}$ The primacy attributed to Zionism stems from the belief that there is a Zionist lobby which presumably 'controls' powerful countries and shapes widespread ideologies, such as capitalism and communism. The RP argues that Zionism aims to establish 'the Greater Israel' and thus it tries to weaken actors, particularly Muslims, who oppose this aim. For the RP, this dynamic is a reflection of a coming conflict between two civilizations that are presumed to exist: a civilization that 'prioritizes brute force' (Kuvveti Üstün Tutan) and one that 'prioritizes the truth' (Hakkı Üstün Tutan). For the RP, the first civilization is represented by 'the West' (which is equated with 'Zionism') and the second is believed to belong to the Muslims and led by Turkey. ${ }^{60}$

Different from the RP, and similar with certain center-right parties, the neoliberal economy is identified as the main dynamic in world politics by the FP and the pre-2007 AKP. In this view, the world is conceived as consisting of developed and underdeveloped countries competing in an international race' shaped by the neoliberal world economy. ${ }^{61}$ The notion of civilization is also central for the FP's and AKP's understandings of world politics. In their views, civilizations are religiously defined and unchanging entities, ${ }^{62}$ providing states with characteristics informing their 'national identity. ${ }^{, 63}$ Particularly in the post-2007 documents of the AKP, civilizational relations are represented as central mechanisms through which world politics unfolds. For that, the AKP suggests that it 'looks into foreign policy and world events through the perspective of civilizations. ${ }^{64}$ The reason for this centrality is related with the belief that Turkey is the 'core state' in its 'sphere of influence' which is determined by its 'civilizational basin' consisting of Turkic and Islamic world. This civilization, in the view of the AKP, is a 'decisive color in today's world. ${ }^{65}$ That said, while concurring with RP in terms of suggesting the existence of multiple civilizations, this view differs from the former in underscoring the possibility of peaceful relations between different civilizations. $^{66}$

Regarding the actors of world politics, the RP considers states as the main actors of world politics. However, in line with the centrality attributed to 'Zionist conspiracies,' the RP identifies certain states, mainly Israel, the United States, and Western European states, as more significant than others. The RP utilizes the term 'external powers' to define these states. The views of the FP and pre-2007 AKP indicate a different take on the actors. 
Particularly informed by their view on globalization (as a process in which capacities of states relatively decrease and power of local and supranational actors increase ${ }^{67}$ ), these parties underline the existence of multiple actors besides states shaping world politics. However, this understanding was dropped by the AKP in its post-2007 period and the primacy of states, especially great powers, was put forward by the party. This emphasis on great powers is informed by the AKP's belief that Turkey is now one of the great powers of world politics. ${ }^{68}$

Such differences and shifts regarding the actors of world politics are also reflected in the Islamist-right parties' understandings of power. Accordingly, power is understood both in material and non-material terms. While sharing similar ideas regarding material power, including economic, military, technological, and demographic elements, there are different views regarding nonmaterial power. For instance, the RP argues that one of the resources that makes 'Zionists' powerful is their ability to mobilize the ideas portraying 'the West' as superior. ${ }^{69}$ In the documents of the FP and pre-2007 AKP, protection of human rights, democratization, and respecting rule of law are identified as non-material elements of power. ${ }^{70}$ In the post-2007 AKP, 'soft power', the capability to influence others through persuasion or attraction, becomes a central notion for understanding non-material power. ${ }^{71}$

Concerning the location of world politics, firstly, the RP has an inwardoriented understanding of inter-state relations which is evident in the party's argument according to which Turkey is the 'main target' of Zionism. ${ }^{72}$ In this sense, the RP argues that the 'external powers' interfered directly into Turkey's domestic affairs with the help of their 'domestic collaborators. ${ }^{, 73}$ Secondly, the views of the FP and pre-2007 AKP transcend this idea of inter-state relations and instead emphasize interactions between multiple actors and their relations as taking place beyond and below state boundaries. For instance, the AKP underscores how respecting human rights and being a democratic country exceed the borders of states and become concerns of the 'world public. ${ }^{74}$ However, this view has been replaced with an understanding according to which world politics is taking place between 'great powers' by the post-2007 AKP. This shift is informed by the changing ideas of the party about Turkey's position in world politics: Turkey now is 'equal' to the other great powers and it is the very relations between these powers that shape world politics.

To summarize, the Islamist-right parties have divergent conceptions of world politics. As demonstrated by the case of the AKP, such divergence may exist even within one individual party. Although all Islamist-right parties view 'the international' as a realm of 'diversity' and/or 'hierarchy,' they identify different reasons for the emergence of such characteristics and propose different solutions to cope with them. Similar divergence also exists regarding the actors and location of world politics. Regarding the 
former, the focus changes from Israel to sub-state and supra-state actors and to great powers. Regarding the latter, a suspicious view on inter-state relations, the idea that world politics takes place below and beyond state boundaries, and the primacy of relations between great powers coexist in Islamist-right parties.

\section{Center-left (CHP, DSP, SHP)}

The CHP was established in 1923 by the founder of the Republic, Mustafa Kemal Atatürk. The party identified itself as 'the left of the center' starting from the mid-1960s. The 1980 coup resulted in the closure of the party, and banned Bülent Ecevit, then the CHP's leader, from politics. After his ban was lifted in 1985, Ecevit founded a new political party, the DSP, while the CHP was reopened again in 1992 under different leadership. The SHP was founded in 1985 as a successor of the CHP. In 1994, the SHP was closed down and merged with the CHP.

The center-left parties' approach to the main dynamics of world politics is informed by two notions: one is 'economy', and the other is 'civilization.' However, the ways in which each party understands and attributes importance to these notions differ. Accordingly, for the SHP and DSP, economy is the main dynamic in world politics. However, the economy in its current manifestation is considered to be generating problems. The DSP underlines the problems initiated by unregulated economy and the 'invisible hand' principle of the liberal economic doctrine. ${ }^{75}$ The SHP concurs and argues that the liberal economy which 'enriches particular people in narrow circles' is the main cause of inequalities and injustices in the world. ${ }^{76}$ Such inequalities are problematized exclusively with reference to their negative effects on the independence of developing and underdeveloped states by the parties. ${ }^{77}$

The second dynamic in world politics is considered as the rules and norms founded by the members of 'contemporary civilization.' The CHP and SHP understand the notion of civilization in a singular term, ${ }^{78}$ i.e. there is one 'universal' civilization possessing values such as development, technology, democracy, and human rights. ${ }^{79}$ The parties incessantly emphasize the necessity to 'lift' Turkey to the level of this civilization so as to ensure the 'survival' of the country. ${ }^{80}$ The DSP, on the other hand, understands civilization in multiple terms, meaning that there are different civilizations, such as Western and Islamic ones, and Turkey's being a crucial actor in world politics depends on its acceptance of its multiple civilizational identities. ${ }^{81}$

The center-left parties consider states as the actors of world politics. However, they view those states which belong to the 'contemporary civilization' as the most significant actors. In this sense, the parties exclusively point to the importance of the United States and Western European states. The institutions founded by these states, particularly NATO and European 
Community/Union are also attributed great importance. ${ }^{82}$ However, the references to the main actors are not always crystal clear. Especially in the DSP and in certain documents of the CHP there are various ambiguous references to 'external powers' who are considered to be the most significant actors having 'bad intentions' towards Turkey. ${ }^{83}$

The views on the main actors are also informed by the ways in which power is understood by the parties. Accordingly, there are both material and nonmaterial sources of power. While material power is mostly associated with economy, technology, or military, non-material power is understood with regards to secularism, democracy and human rights. ${ }^{84}$ It is especially the notion of secularism that the parties prioritize in their understandings of non-material power. For them, 'the greatest source of power for Turkey in the international realm is secularism' which is considered to be the 'cornerstone' of various achievements of Turkey, from country's national integrity to the protection of 'contemporary and civilized state order and way of life. ${ }^{85}$

The parties identify inter-state relations as the location of world politics. However, there are two understandings that can be teased out in centralleft parties' take on this location. Firstly, such as in the case of the SHP, a positive outlook that underscores the importance of cooperative relations between states exists. ${ }^{86}$ Secondly, as it is evident in the DSP and CHP, there is also an inward-oriented view. This view focuses on the 'threats' posed by 'external powers' who utilize domestic 'collaborators' so as to weaken Turkey. ${ }^{87}$ For instance, the DSP argues that there are various actors, such as Russia, certain Middle Eastern countries, and Greece, who long for the 'division' of Turkey. ${ }^{88}$ For the CHP, terror has been utilized as 'a covert and asymmetrical tool in international relations' which aims to destabilize Turkey. ${ }^{89}$ For the party, there is also 'an international strategy against secularism' which 'targets' the country. 90

To summarize, the center-left parties view 'the international' as a hierarchical realm in which actors are differentiated based on two criteria: economy and civilization. The views on the actors point to two, somewhat contradictory, ideas. Firstly, states belonging to the 'contemporary civilization', are considered as the most significant actors. Secondly, there are ambiguous references towards 'external powers,' which include, but are not limited to, the very actors belonging to the 'contemporary civilization.' Regarding the location of world politics, a suspicious inward-oriented and positive cooperative inter-state relations idea exist in the documents of different parties.

\section{Pro-Kurdish (HADEP, DEHAP, HDP)}

The HADEP was established in 1994, as a successor of the People's Labor Party (HEP) (1990-93) and the Democracy Party (DEP) (1993-94) which were closed down on the grounds that they engaged with separatist activities. 
The HADEP was also closed down in 2003 on the same grounds and it was replaced with the DEHAP. The DEHAP was formed in 1997 and existed until 2005 when it merged with the Democratic Society Party (DTP) (200509). The HDP was founded in 2012.

Two views found in the documents of pro-Kurdish political parties point to their understandings of the main dynamic of world politics. ${ }^{91}$ Firstly, they argue that neoliberal economy is central mechanism through which world politics occurs. ${ }^{92}$ Neoliberalism is understood as a negative phenomenon in that it is considered as the main reason behind the problems of the world including 'the economic gap between Northern and Southern Hemisphere,' ecological degradation, and gender inequality. ${ }^{93}$ The second dynamic shaping world politics is considered to be the process through which a diffusion of state authority both towards supra-state as well as intra-state levels and increasing consciousness on human rights and 'anti-democratic' practices of states among the 'world public' become prevalent. ${ }^{94}$

This view on the main dynamics of world politics also manifests itself in the parties' understanding of the actors of world politics. In this regard, two particular points can be emphasized. Firstly, although highlighting their centrality for world politics, pro-Kurdish parties are critical of states, in a way that does not exist in other political parties of Turkey. This criticism, although mostly centered on Turkey, is also directed to economically advanced countries who are initiating various inequalities in the world. ${ }^{95}$ Secondly, for the pro-Kurdish parties there are multiple other actors besides states shaping various aspects of world politics. These include subnational and transnational actors such as municipal bodies or international human rights organizations. In this sense, for the parties, the power of actors in world politics does not only stem from material resources but also from their approaches to human rights, rule of law and democracy. ${ }^{96}$

The view regarding the location of world politics suggests that there are multiple locations (local, national, and global) in which world politics unfolds and boundaries between them are 'porous.' ${ }^{97}$ This multiplicity manifests itself in different issue areas, such as in economy through policies informed by neoliberalism that transcend state boundaries or in human rights discussions which have become a common concern for the world public. $^{98}$ In this sense, for pro-Kurdish parties the location of world politics goes beyond inter-state relations.

To summarize, in the view of the pro-Kurdish parties, neoliberal economy and the diffusion of state authority make the world go around. Alongside states, which they are critical of, the pro-Kurdish parties point to sub-state and supra-state entities as the actors of world politics. These parties identify diverse local, national, and global realms as locations where world politics takes place. 


\section{Conclusion}

This article analyzed the conceptions of 'the international' as found in one of the non-core actors of world politics, namely Turkey, by focusing on how the political parties of the country view main dynamics, main actors, and the locations of world politics. In doing so, it differentiates itself from the FPA literature (which examines the impact of ideational factors on foreign policy) by taking 'the international' as its central concept and discussing it with reference to IR theorizing. As detailed above, there are significant differences between political parties' conceptions. Here, I will point to shared characteristics so that I can identify the contours of the conception of 'the international' in Turkey as an example of a non-core context. I will also discuss these conceptions' implications for IR, so as to reveal what the mainstream of the discipline misses by overlooking non-core actors' conceptions of 'the international'.

One significant similarity between Turkey's political parties regarding the main dynamic of world politics is that they all identify 'hierarchy' in world politics. For some, the source of such hierarchy is material, as with 'inequality.' While some explains this inequality with reference to 'hypocritical behaviors' or 'secret intentions' of 'Western' actors, some others point to neoliberal economy as the main source of inequality in world politics. Another source of hierarchy is explained with reference to non-material sources, particularly 'civilization.' While some parties view civilization in 'evaluative-normative' terms in a sense that for them 'the world [is] divided into "civilized" and "less-than-civilized" categories', some others consider it in 'ethnographic' terms, underscoring that there are multiple civilizations which either clash, or coexist peacefully. ${ }^{99}$ These views raise significant challenges to IR's mainstream perspectives take on 'the international' which they consider as a realm of 'anarchy' under which juridically-equal sovereign states long for military power to ensure their 'survival. ${ }^{100}$ In doing so, they overlook how the ideas and experiences of non-core actors (in this case Turkey) point to 'hierarchy' in world politics. ${ }^{101}$ In understanding the material capabilities (mostly military) as central to how the world works, the mainstream perspectives do also overlook how non-core actors make sense of the world through the prism of non-material factors as well.

Concerning the second component of 'the international', i.e. the main actors of world politics, one common characteristic shared by political parties is the idea of 'diversity' between states in world politics. Similar to the first finding on hierarchy, diversity is not only understood materially, but also ideationally. In this sense, what makes some states more important than others in world politics is not only related with their material capabilities but also with their non-material characteristics (such as civilizational identities) or their abilities to influence and shape dominant ideas and representations in world politics. Secondly, when making sense of the powerful 
actors, a majority of the political parties utilize vague and ambivalent ${ }^{102}$ notions, such as 'external powers.' These findings, in turn, challenge the mainstream theories' views on actors in a twofold manner. Firstly, the idea of 'diversity' goes beyond mainstream theories' understandings of states as 'like units,' domestic characteristics of which do not affect world politics. ${ }^{103}$ Secondly, the findings contest the mainstream perspectives' great powercentric ways of theorizing world politics. This is because while it is well recognized by the political parties that some actors are more important than others in world politics, these actors do not always consist of great powers as it is traditionally understood in the literature. The centrality of certain middle powers (such as Israel) or some unspecified non-state actors (such as international civil society organizations') for political parties is a case in point.

Finally, Turkey's political parties identify inter-state relations as the main location of world politics. For them, domestic and foreign realms are separate. Yet, the majority of the political parties view inter-state relations in an inwardoriented manner. That is to say, they are primarily concerned with the incessant influence (understood mostly in negative terms) of the external realm on shaping the dynamics within the domestic domain. This view goes against the prevalent idea in mainstream theories which deems the study of domestic politics unnecessary in studying world politics. This is because for them the interactions between great powers alone explain where world politics unfolds. ${ }^{104}$ Yet, in Turkey the dominant idea associates domestic developments, both in Turkey and elsewhere, with the activities of those actors residing 'outside.' In fact, there is a widespread view shared by a majority of the political parties that world politics mostly manifests itself within a country, in this case Turkey.

\section{Notes}

1. Seth, "Historical Sociology."

2. Throughout the article, the term 'core' refers to the Western European and North American actors, while 'non-core' refers to those actors who are 'less influential,' 'non-dominant,' and/or 'non-privileged' in world politics; Waever and Tickner, "Introduction," 1.

3. Bilgin, The International; Jabri, The Postcolonial; Seth, "Introduction"; and Seth, "Postcolonial Theory and the critique."

4. Turkey exemplifies a non-core context since, although not formally colonized, it was 'nevertheless caught up in hierarchies that were built and sustained during the age of colonialism and beyond.' See Bilgin, The International, 7-8.

5. See, among others, Altunışuk, "Worldviews"; Aras and Görener, "National"; Arkan and Kınacıoğlu, "Enabling"; Cohen, "Ahmet Davutoğlu's"; Görener and Uçal, "The Personality"; Mufti, "The AK Party's"; Öniş, "Conservative"; and Yeşiltaş, "The Transformation." Due to space limitations, more extensive treatment of this literature is beyond the scope of this article.

6. Barkawi and Laffey, "Retrieving," 111.

7. Jabri, The Postcolonial, 2. 
8. Bilgin, The International; Blaney and Inayatullah, "International Relations"; Grovogui, Beyond Eurocentrism; Jabri, The Postcolonial; Seth, Postcolonial Theory; and Shilliam, International Relations.

9. Seth, "Postcolonial Theory and the Critique," 28.

10. Jabri, The Postcolonial, 8-9.

11. Ling, The Dao, 1.

12. Hobson, The Eastern; Seth, Postcolonial Theory; and Shilliam, International Relations.

13. Seth, "Postcolonial Theory and the Critique," 28.

14. Muppidi, The Politics, 16.

15. Seth, "Introduction," 2-3.

16. Grovogui, Beyond Eurocentrism, 16-7. This literature differs from the one which engages with non-core actors with the aim to develop national schools of IR. For a detailed discussion, see Bilgin, “Thinking Past 'Western' IR"; and Seth, "Introduction."

17. Bilgin, The International, 45.

18. Tickner and Blaney, "Introduction," 13.

19. Bilgin, The International, 7.

20. Jabri, The Postcolonial, 29.

21. Booth, Theory of World Security, 154.

22. Rosenau, Along the Domestic-Foreign Frontier, 32.

23. Frey, The Turkish Political Elite, 301; Özbudun, "Contemporary Turkish Politics," 99; and Sayarı, "Political Parties," 191.

24. Ó Tuathail and Agnew, "Geopolitics," 192-3.

25. In grouping the parties, I draw on the studies of those prominent scholars focusing on the party system in Turkey. See Heper, "The Mainstream"; Özbudun, "Changes and Continuities"; Sayarı, "Towards a New"; and Sayar1, "Political Parties."

26. Sayarı, "Political Parties."

27. Sayarı, "The Changing Party System," 12.

28. Ibid., 17.

29. The discussion ends with 2015 because this is the year when the last general elections in Turkey were held. Unless stated otherwise, I accessed the documents from Grand National Assembly's open access website. See http:// acikerisim.tbmm.gov.tr/.

30. Bilgin, "A return."

31. Sayar1, "Political Parties," 187.

32. For instance, in the 2002 general elections, the parties passed the election threshold received 53.4 percent of the overall votes, while it is 90.1 percent for the parties received at least one-million votes. Similar percentages are also evident in other elections. For the election results, see http://www.tuik. gov.tr/.

33. Throughout the article, the Turkish abbreviations of the political parties are used.

34. MHP Seçim Beyannamesi, 2.

35. 2023'e Doğru, 9.

36. For the detailed analysis on the centrality of this part of the world for MHP, see Bora and Can, Devlet, Ocak, Dergâh.

37. MHP Seçim Beyannamesi, 2; and 2023'e Doğru, 9.

38. Geleceğe Doğru, 131. 
39. Milli Duruş, 113.

40. Lider Türkiye'ye Doğru, 8; and Milli Duruş, 4. In the literature, this view is frequently associated with the 'Sèvres syndrome.' The syndrome is named after the treaty of Sèvres which was a post-World War One pact between Allied powers and Ottoman Empire. Although they were never implemented, the terms of the treaty provided the partition of the Ottoman Empire by the Allies and the establishment of new Kurdish and Armenian states. The syndrome, on the other hand, refers to the fear of dismantlement of Turkey through the 'plots' of 'external powers' and their internal 'collaborators.' As it will be examined in the following sections, this view is widespread among different political parties in Turkey. For the historical and contextual analysis of the syndrome and its centrality for Turkish politics, see, among others, Bilgin, "Turkey's 'Geopolitics Dogma”"; Göçek, The Transformation; Guida, "The Sèvres syndrome”; Kirişçi, "Turkey and the Mediterranean”; and Nefes, "Political Parties'."

41. MHP Seçim Beyannamesi, 23-4.

42. MHP Programi, 3.

43. 2023'e Doğru, 1-2.

44. MHP Seçim Beyannamesi, 1. As it will be demonstrated below, 'external powers' is a widely used expression in the discourses of different political parties. On the general definition of the term, see Aslandaş and Bıçakçı, Populer Siyasi Deyimler Sözlüğ̈̈, 72-73.

45. Lider Türkiye'ye Doğru, 8.

46. Türkiye'nin Onurlu Geleceği, 2.

47. Mill Duruş, 29-30. Depending on the issue, both MHP and other political parties use the expression 'collaborators' in a way to imply different groups in Turkey such as non-Muslim minorities. See, for instance, Nefes, "Understanding" and "Political Parties'."

48. Türkiye’nin Onurlu Geleceği, 13.

49. Scholte, Globalization: A critical Introduction, 56.

50. 21 Ekim Sabahi, 3.

51. DP Seçim Beyannamesi, 104.

52. Ibid., 97-8.

53. ANAP Seçim Beyannamesi, 94; and 21 Ekim Sabahı, 316.

54. 21 Ekim Sabahı, 252-3 and 263-4.

55. GP Programi, 3.

56. DP Seçim Beyannamesi, 21.

57. Ibid., 104.

58. Scholte, Globalisation: A Critical Introduction, 16.

59. For an analysis tracing the reasons for and the centrality of this idea in Islamistright political parties in Turkey, see Bali, "The Image of the Jew."

60. Yeni Bir Dünya, 4-6.

61. Öncü Türkiye İçin, 6-7, and Her şey Türkiye için, 7.

62. Bowden, "Civilizational Security", and Bilgin and Bilgiç, "Turkey's 'New' Foreign Policy."

63. AK Parti 2007 Genel Seçimleri, 196, and Türkiye Hazır, 145-6.

64. Türkiye Hazır, 274.

65. Ibid., 86.

66. Ibid., 150.

67. Her şey Türkiye için, 33.

68. Yeni Türkiye, 324. 
69. Yeni Bir Dünya, 14.

70. Her şey Türkiye İçin, 25.

71. Nye, Soft Power.

72. Yeni Bir Dünya, 14.

73. Ibid., 115.

74. Her şey Türkiye için, 17.

75. DSP Programi, 86.

76. Yeni Bir Türkiye İçin, 10.

77. SHP Tüzük, 126.

78. Bowden, "Civilizational Security."

79. Özgürlüğ̈̈n ve Umudun Ülkesi, 123-4.

80. For an analysis explaining the reasons for this view with reference to the early Republican era see Bilgin, "Securing Turkey."

81. Bilgin and Bilgiç, "Turkey's New Foreign Policy."

82. SHP Tüzük, 165-7.

83. DSP Programi, 70.

84. Yeni Hedefler, Yeni Türkiye, 3.

85. DSP Programı, 10, and Güzel Günler Göreceğiz, 81.

86. SHP Tüzük, 166.

87. Gözünaydın Türkiye, 4, and DSP ile Dürüst Yönetim, 2.

88. Gözünaydın Türkiye, 5, and DSP ile Dürüst Yönetim, 3.

89. Pusula, 7.

90. Yeni Hedefler, Yeni Türkiye, 20.

91. The term 'pro-Kurdish' refers to a political, not an ethnic identity. While the Kurdish problem is the dominant issue on these parties' agendas, not every member of the parties is ethnically Kurdish. See Watts, "Allies and Enemies," 651.

92. HDP Program, 1.

93. DEHAP Program, 67 and 18-21.

94. HADEP Program, 5.

95. Ibid., 4-5.

96. DEHAP Program ve Tüzük, 7.

97. Rosenau, Along the Domestic-Foreign Frontier.

98. HADEP Program, 5 and 13-4.

99. Bilgin and Bilgiç, "Turkey's 'New' Foreign Policy," 180-1.

100. Waltz, Theory of International Politics, and Mearsheimer, The Tragedy.

101. Bilgin, The International, 1.

102. Bilgin and Bilgiç, "Turkey and EU/rope."

103. Waltz, Theory of International Politics, 93.

104. Mearshimer, The Tragedy.

\section{Acknowledgements}

Previous versions of this article were presented at the 11th Pan-European Conference on International Relations 2017, Barcelona, Spain and at WISC ECR Workshop 2017, Goa, India. I would like to thank to the discussants and audiences at the conference and at the workshop for their helpful comments. I would like to thank Pinar Bilgin for her valuable insights and suggestions on the earlier drafts. I would also like to thank Hakan Sipahioğlu, Neslihan Dikmen Alsancak, Zeynep Gülşah Çapan, Gözde Turan, and the anonymous reviewers for their ideas and criticisms. All remaining errors are my own. 


\section{Disclosure statement}

No potential conflict of interest was reported by the author.

\section{Note on contributor}

Mine Nur Küçük has a Ph.D. from the Department of International Relations, Bilkent University. She holds a B.Sc. in International Relations from Middle East Technical University and an MA in International Relations from the University of Nottingham.

\section{Bibliography}

2023'e Doğru Yükselen Ülke Türkiye Sözleşmesi: MHP Seçim Beyannamesi [Turkey’s Contract as a Rising Country to 2023: MHP Election Manifesto], 2011. https:// www.mhp.org.tr/usr_img/_mhp2007/kitaplar/MHP_2011_SecimBeyannamesi.pdf.

21 Ekim Sabahı Yeni Bir Türkiye: DYP Seçim Bildirgesi [A New Turkey on the Morning of October 21st: DYP Election Manifesto], 1991. http://hdl.handle.net/ $11543 / 679$.

AK Parti 2007 Genel Seçimleri Seçim Beyannamesi [AK Party 2007 General Elections Manifesto], 2007. http://www.akparti.org.tr/site/dosyalar\#!/ak-parti-hukumetprogramlari.

Altunışı, Meliha Benli. "Worldviews and Turkish Foreign Policy in the Middle East." New Perspectives on Turkey 40 (Spring 2009): 171-194.

ANAP Seçim Beyannamesi [ANAP Election Manifesto], 1991. http://hdl.handle.net/ $11543 / 675$.

Aras, Bülent, and Aylin Gorener. "National Role Conceptions and Foreign Policy Orientation: The Ideational Bases of the Justice and Development Party's Foreign Policy Activism in the Middle East." Journal of Balkan and Near East Studies 12, no. 1 (2010): 73-92.

Arkan, Zeynep, and Müge Kınacıŏlu. "Enabling 'Ambitious Activism': Davutoğlu's Vision of a New Foreign Policy Identity for Turkey." Turkish Studies 17, no. 3 (2016): 381-405.

Aslandaş, Alper Sedat, and Baskın Bıçakçı. Popüler siyasi deyimler sözlüğ̈̈ [Dictionary of Popular Political Idioms]. İstanbul: İletişim, 1995.

Bali, Rifat N. "The Image of the Jew in the Rhetoric of Political Islam in Turkey." Cahiers d'études sur la Méditerranée Orientale et le Monde Turco-Iranien 28, (1999): 95-108. [Online] URL: http://journals.openedition.org/cemoti/590.

Barkawi, Tarak, and Mark Laffey. "Retrieving the Imperial: Empire and International Relations." Millennium: Journal of International Studies 31, no. 1 (2002): 109-127.

Bilgin, Pinar. The International in Security, Security in the International. London: Routledge, 2016.

Bilgin, Pınar. "A Return to 'Civilisational Geopolitics' in the Mediterranean? Changing Geopolitical Images of the European Union and Turkey in the Postcold War Era." Geopolitics 9, no. 2 (2004): 269-291.

Bilgin, Pınar. "Securing Turkey Through Western-oriented Foreign Policy." New Perspectives on Turkey, no. 40 (2009): 105-125.

Bilgin, Pınar. “Thinking Past 'Western' IR?” Third World Quarterly 29, no. 1 (2008): 5-23.

Bilgin, Pınar. “Turkey's 'Geopolitics Dogma'.” In The Return of Geopolitics in Europe? Social Mechanism and Foreign Policy Identity Crisis, edited by Stefano Guzzini, 152-174. Cambridge: Cambridge University Press, 2013. 
Bilgin, Pınar, and Ali Bilgiç. "Turkey and EU/Rope: Discourses of Inspiration/Anxiety in Turkey's Foreign Policy.” Review of European Studies 4, no. 3 (2012): 111-124. Bilgin, Pınar, and Ali Bilgiç. "Turkey's 'New' Foreign Policy Toward Eurasia." Eurasian Geography and Economics 52, no. 2 (2011): 173-195.

Blaney, David L., and Naeem Inayatullah. "International Relations from Below." In Oxford Handbook of International Relations, edited by Christian Reus-Smith and Duncan Snidal, 663-674. Oxford: Oxford University Press, 2008.

Booth, Ken. Theory of World Security. Cambridge: Cambridge University Press, 2007.

Bora, Tanıl, and Kemal Can. Devlet ocak, dergâh: 12 Eylül'den 1990'lara ülkücü hareket [State, Heart and House: The Idealist Movement from 12 September until the 1990s]. İstanbul: İletişim, 2000.

Bowden, Brett. "Civilizational Security." In The Routledge Handbook of New Security Studies, edited by J. Peter Burgess, 7-16. London: Routledge, 2010.

Cohen, Matthew S., "Ahmet Davutoğlu's Academic and Professional Articles: Understanding the World View of Turkey's Former Prime Minister." Turkish Studies 17, no. 4 (2016): 527-543.

DEHAP Program ve Tüzük [DEHAP Program and By-law], 2003. http://hdl.handle. net/11543/911.

DP Seçim Beyannamesi [DP Election Manifesto], 2007. http://hdl.handle.net/11543/ 876.

DSP ile Dürüst Yönetim, Hakça Düzen, Ulusal Birlik: DSP’nin Seçim Bildirgesi [Honest Administration, Fair System, National Unity with DSP: Election Manifesto of DSP], 1995. http://hdl.handle.net/11543/764.

DSP Programı [DSP Program], 2003. http://hdl.handle.net/11543/861.

Frey, Frederick. The Turkish Political Elite. Cambridge, MA: MIT Press, 1965.

Geleceğe Doğru: MHP Parti Programı [Towards the Future: MHP Program], 2009. http://hdl.handle.net/11543/923.

Göçek, Fatma Müge. The Transformation of Turkey: Redefining State and Society from the Ottoman Empire to the Modern Era. London: I. B. Tauris, 2011.

Görener, Aylin Ş., and Meltem Ş. Ucal. "The Personality and Leadership Style of Recep Tayyip Erdoğan: Implications for Turkish Foreign Policy.” Turkish Studies 12, no. 3 (2011): 357-381.

Gözünaydın Türkiye: DSP’nin Seçim Bildirgesi [Good News, Turkey: Election Manifesto of DSP], 1991. http://hdl.handle.net/11543/602.

GP Programı [GP Program], 2007. http://hdl.handle.net/11543/893.

Grovogui, Siba N. Beyond Eurocentrism and Anarchy: Memories of International Order and Institutions. New York: Palgrave MacMillan, 2006.

Guida, Michelangelo. "The Sévres Syndrome and 'Komplo' Theories in the Islamist and Secular Press.” Turkish Studies 9, no. 1 (2008): 37-52.

Güzel Günler Göreceğiz: CHP Seçim Bildirgesi [We Will See Good Days: CHP Election Manifesto], 2002. http://hdl.handle.net/11543/955.

HADEP Program, 1994. http://hdl.handle.net/11543/745.

HDP Program, 2013. http://www.hdp.org.tr/tr/parti/parti-programi/8.

Heper, Metin. "The Mainstream Political Parties in Republican Turkey, 1923-1999.” In Turkey in the Twentieth Century-La Turquie au Vingtieme Siecle, edited by Eric Jan Zürcher, 147-181. Berlin: Klaus Schwarz Verlag, 2008.

Her şey Türkiye İçin: AK Parti Seçim Beyannamesi [Everything is for Turkey: AK Party Election Manifesto], 2002. http://hdl.handle.net/11543/954.

Hobson, John M. The Eastern Origins of Western Civilization. Cambridge: Cambridge University Press, 2004. 
Jabri, Vivienne. The Postcolonial Subject: Claiming Politics/Governing Others in Late Modernity. London: Routledge, 2013.

Kirisci, Kemal. “Turkey and the Mediterranean.” In The Foreign Policies of European Union's Mediterranean States and Applicant Countries in the 1990s, edited by Stelios Stavridis, Theodore Couloumbis, Thanos Veremis, and Neville Waites, 250-294. London: McMillan, 1999.

Lider Türkiye'ye Doğru: MHP Seçim Beyannamesi [The Truth to Leader Turkey: MHP Election Manifesto], 1999. http://hdl.handle.net/11543/740.

Ling, L. H. M. The Dao of World Politics: Towards a Post-Westphalian, Worldist International Relations. London: Routledge, 2014.

Mearsheimer, John J. The Tragedy of Great Power Politics. New York: Norton, 2001. MHP Programı [MHP Program], 2000. http://hdl.handle.net/11543/859.

MHP Seçim Beyannamesi [MHP Election Manifesto], 1995. http://hdl.handle.net/ $11543 / 762$.

Milli Duruş Ve Kararlılık Belgesi: MHP Seçim Beyannamesi [The National Attitude and Persistence Testimonial: MHP Election Manifesto], 2007. http://hdl.handle. net/11543/919.

Mufti, Malik. "The AK Party's Islamic Realist Political Vision: Theory and Practice." Politics and Governance 2, no. 2 (2014): 28-42.

Muppidi, Himadeep. The Politics of the Global. Minneapolis: University of Minnesota Press, 2004.

Nefes, Türkay Salim. "Political Parties' Perceptions of Uses of Anti-semitic Conspiracy Theories in Turkey." The Sociological Review 61, no. 3 (2013): 247-264.

Nefes, Türkay Salim. "Understanding Anti-semitic Rhetoric in Turkey Through the Sévres Syndrome.” Turkish Studies 16, no. 4 (2015): 572-587.

Nye, Joseph S. Soft Power: The Means to Success in World Politics. New York: Public Affairs Press, 2004.

Öncü Türkiye için El Ele: FP Kalkınma Programı [Hand in Hand for the Pioneer Turkey: FP Development Program], 1998. http://hdl.handle.net/11543/698.

Öniş, Ziya. "Conservative Globalists versus Defensive Nationalists: Political Parties and Paradoxes of Europeanization in Turkey." Journal of Southern Europe and the Balkans Online 9, no. 3 (2007): 247-261.

Ó Tuathail, Gearoid and John Agnew. "Geopolitics and Discourse: Practical Geopolitical Reasoning in American Foreign Policy.” Political Geography 11, no. 2 (1992): 190-204.

Özbudun, Ergun. "Changes and Continuities in the Turkish Party System." Representation 42, no. 2 (2006): 129-137.

Özbudun, Ergun. Contemporary Turkish Politics: Challenges to Democratic Consolidation. Boulder, CO: Lynne Rienner Publishers, 2000.

Özgürlüğün ve Umudun Ülkesi, Herkesin Türkiye'si: CHP Seçim Bildirgesi [The Country of Freedom and Hope, Turkey of Everyone: CHP Election Manifesto], 2011. http://www.chp.org.tr/wp-content/uploads/secim_bildirgesi-web.pdf.

Pusula: CHP Seçim Bildirgesi [Compass: CHP Election Manifesto], 2007. http://www. chp.org.tr/wp-content/uploads/Pusula_2007.pdf.

Rosenau, James N. Along the Domestic-foreign Frontier: Exploring Governance in a Turbulent World. Cambridge: Cambridge University Press, 1997.

Sayarı, Sabri. "The Changing Party System." In Politics, Parties, and Elections in Turkey, edited by Sabri Sayarı and Yllmaz Esmer, 9-32. Boulder: Lynne Rienner Publishers, 2002. 
Sayarı, Sabri. "Political Parties." In The Routledge Handbook of Modern Turkey, edited by Metin Heper and Sabri Sayar1, 182-193. London: Routledge, 2012.

Sayarı, Sabri. “Towards a New Turkish Party System?” Turkish Studies 8, no. 2 (2007): 197-210.

Scholte, Jan Aart. Globalization: A Critical Introduction. 2nd ed. Basingstoke: Palgrave Macmillan, 2005.

Seth, Sanjay. "Historical Sociology and Postcolonial Theory: Two Strategies for Challenging Eurocentrism." International Political Sociology 3, no. 3 (2009): 334-338.

Seth, Sanjay. "Introduction." In Postcolonial Theory and International Relations: A Critical Introduction, edited by Sanjay Seth, 1-12. London: Routledge, 2013.

Seth, Sanjay. "Postcolonial Theory and the Critique of International Relations." In Postcolonial Theory and International Relations: A Critical Introduction, edited by Sanjay Seth, 15-31. London: Routledge, 2013.

Seth, Sanjay, ed. Postcolonial Theory and International Relations: A Critical Introduction. London: Routledge, 2013.

Shilliam, Robbie, ed. International Relations and non-Western Thought: Imperialism, Colonialism, and Investigations of Global Modernity. London: Routledge, 2011.

SHP Tüzük, Program ve Grup İç Yönetmeliği [SHP By-law, Program and In-group Regulations], 1990. http://hdl.handle.net/11543/676.

Tickner, Arlene B., and David L. Blaney. "Introduction: Thinking Difference." In Thinking International Relations Differently, edited by Arlene B. Tickner and David L. Blaney, 1-24. London: Routledge, 2012.

Türkiye Hazır Hedef 2023: AK Parti Seçim Beyannamesi [Turkey is Ready, the Goal is 2023: AK Party Election Manifesto], 2011. http://www.akparti.org.tr/site/ dosyalar\#!/ak-parti-hukumet-programlari.

Türkiye'nin Onurlu Geleceği: MHP Seçim Beyannamesi [The Honorable Future of Turkey: MHP Election Manifesto], 2002. http://hdl.handle.net/11543/938.

Waever, Ole and Arlene B. Tickner. "Introduction: Geocultural Epistemologies." In International Relations Scholarship Around the World, edited by Arlene B. Tickner and Ole Waever, 1-31. London: Routledge, 2009.

Waltz, Kenneth N. Theory of International Politics. Reading, MA: Addison-Wesley, 1979.

Watts, Nicole F. “Allies and Enemies: Pro-Kurdish Parties in Turkish Politics, 199094." International Journal of Middle Eastern Studies 31, no. 4 (1999): 631-656.

Yeni Bir Dünya, "Mutluluk": RP Seçim Beyannamesi [A New World, "Happiness": RP Election Manifesto], 1991. http://hdl.handle.net/11543/672.

Yeni Bir Türkiye İçin İlk Hedefler: SHP Seçim Bildirgesi [The First Goals for a New Turkey: SHP Election Manifesto], 1991. https://www.tbmm.gov.tr/develop/ owa/e_yayin.eser_bilgi_q?ptip=SIYASI\%20PARTI\%20YAYINLARI\&pdemirbas= 199106301.

Yeni Hedefler, Yeni Türkiye: CHP Programı [New Goals, New Turkey: CHP Program], 1994. http://hdl.handle.net/11543/956.

Yeni Türkiye Yolunda Daima Adalet, Daima Kalkınma: AK Parti Seçim Beyannamesi [Always Justice, Always Development on the Way to New Turkey: AK Party Election Manifesto], 2015. http://www.akparti.org.tr/site/dosyalar\#!/ak-partihukumet-programlari.

Yeşiltaş, Murat. "The Transformation of the Geopolitical Vision in Turkish Foreign Policy.” Turkish Studies 14, no. 4 (2013): 661-687. 